\title{
Virulence of Beauveria bassiana and Metarhizium anisopliae on different stages of the pink bollworm, Pectinophora gossypiella (Saunders) (Lepidoptera: Gelechiidae)
}

\author{
Gamal Omar ${ }^{1}$, Ahmed Ibrahim² and Khalid Hamadah ${ }^{1^{*}}$ (D)
}

\begin{abstract}
Background: The pink bollworm, Pectinophora gossypiella, is the most destructive pests of the cotton plant in Egypt. Due to the several problems of insecticides, the present study was conducted to evaluate the toxicity effect of the entomopathogenic fungi (EPF), Beauveria bassiana and Metarhizium anisopliae, against the different stages of the pink bollworm, Pectinophora gossypiella (Saunders) (Lepidoptera: Gelechiidae)

Results: The fungal isolates exhibited a toxic effect against the treated stages, egg, larva, and pupa. According to the obtained data of $L C_{50}$, B. bassiana was more potent in inducing toxicity than $M$. anisopliae. However, eggs of $P$. gossypiella were less susceptible to the EPF than the other stages. Based on total mortality, $L_{50}$ was $4.97 \times 10^{11}, 6.03 \times 10^{12}$ spores $/ \mathrm{ml}$ for egg; $8.25 \times 10^{8}, 6.03 \times 10^{9}$ spores $/ \mathrm{ml}$ for neonate; $2.52 \times 10^{8}, 1.29 \times 10^{10}$ spores $/ \mathrm{ml}$ for early 4 th instar larvae; and $6.79 \times 10^{8}, 8.36 \times 10^{9}$ spores $/ \mathrm{ml}$ for pupae after treatment with B. bassiana and M. anisopliae, respectively.

Conclusions: Entomopathogenic fungi exhibited an activity in inducing mortality against different stages of $P$. gossypiella.
\end{abstract}

Keywords: Entomopathogenic fungi, Pink bollworm, Pectinophora gossypiella, Mortality

\section{Background}

The pink bollworm, Pectinophora gossypiella (Saunders) (Lepidoptera: Gelechiidae), is one of the most injurious cotton pests worldwide (Parmar and Patel 2016). It decreases quantities and qualities of the cotton yield (Moustafa et al. 2019).

Because of the adverse effects of chemical insecticides to human and environment generally, there is a serious need for insecticidal alternatives. Microbial insecticides such as fungus, bacterium, virus, or protozoan are one of such alternatives characterized by not having chemical residues and/or insect resistance (Dhakal and Singh 2019).

\footnotetext{
*Correspondence: khalid_hamadah@azhar.edu.eg

'Zoology and Entomology Department, Faculty of Science, Al-Azhar

University, Madinat Nasr, Cairo, Egypt

Full list of author information is available at the end of the article
}

More than 700 species of EPF were widely used as biopesticides (e.g., B. bassiana, M. anisopliae, Verticillium lecanii, Purpureocillium lilacinum, and Isaria fumosorosea) against many agricultural pests (Rizwan et al. 2019). EPF are present within natural insect populations and are often considered as an effective microbial control agent in integrated pest management (Vega et al. 2009). The mode of action of the EPF is through invading the insect cuticle and production of toxic enzymes that overcome the insect immune system (Niu et al. 2019).

EPF proved its effect against eggs, immature stages, and adult stage of many insect species (Hanem 2012) in both natural and artificial ecosystem (Cuthbertson and Audsley 2016). There is a growing interest to use them as a biocontrol agent in integrated pest management programs (Ali et al. 2017). The present study aimed to 
evaluate the virulence of EPF, B. bassiana and M. anisopliae, against the $P$. gossypiella different stages under laboratory conditions.

\section{Methods}

\section{Rearing of insect}

A culture of $P$. gossypiella was established under constant laboratory conditions of $\left(27 \pm 1{ }^{\circ} \mathrm{C}\right.$ and $65 \%$ R.H $)$ in a rearing room at the Bio Insecticides Production Unit, Plant Protection Research Institute, Giza, Egypt. The neonate larvae were reared on an artificial diet described by Rashad et al. (1993). The pupae were placed in clean glass vials plugged with cotton until moth emergence.

\section{Entomopathogenic fungi}

Entomopathogenic fungi isolates, used in the present study, were B. bassiana and M. anisopliae. B. bassiana was isolated from the red palm weevil, Rhynchophorus ferrugineus in Ismailia governorate, while $M$. anisopliae was isolated from the white fly, Bemisia tabaci (Genn.) in Sharkia governorate (Ibrahim 2006).

\section{Mass production of entomopathogenic fungi}

The obtained conidia from fungal culture of $B$. bassiana and $M$. anisopliae were grown at $25{ }^{\circ} \mathrm{C}$, in dark, on Sabouraud dextrose agar (SDA), consisting of peptone $10 \mathrm{~g} / \mathrm{l}$, glucose 20g/l, and agar-agar $20 \mathrm{~g} / \mathrm{l}$, (constant volume of $15 \mathrm{ml}$ ) in standard Petri-dishes (9-cm diameter). Conidia were harvested from 15-day-old plates by scraping into sterile Triton-X. The suspension was vortexed for $2 \mathrm{~min}$ and agitated for $1.5 \mathrm{~h}$ on a flask shaker at room temperature before filtering through 4 layers of sterile muslin. The conidial concentrations were estimated stock suspension were estimated using an improved Neubauer bright line hemocytometer (Reichert) under a Leitz Dialux $\times 40$ EB microscope (400× magnification). A series of dilutions were made to give range concentrations of $10^{8}, 10^{9}, 10^{10}, 10^{11}$, and $10^{12}$ spores/ $\mathrm{ml}$.

\section{Bioassay}

To study the virulence of $M$. anisopliae and B. bassiana against the different stages of pink bollworm $P$. gossypiella, 5 concentrations of each fungus $\left(10^{8}, 10^{9}, 10^{10}\right.$, $10^{11}$, and $10^{12}$ (spores $\left./ \mathrm{ml}\right)$ ) were prepared. All studies were carried out and incubated at $27 \pm 1^{\circ} \mathrm{C}$ and $65 \%$ R.H.

\section{Treatment of eggs}

Egg cards of $P$. gossypiella were sprayed using air brush directly with 5 concentrations of each EPF through laboratory bioassays then placed into plastic container measuring $7 \times 5 \mathrm{~cm}$ and observed daily for the number of hatched larvae in each treatment. Four replicates (50 eggs/replicate). Control eggs were treated with water only.

Treatment of newly hatched larvae (neonate)

Concentrations of fungi were homogeneously mixed with artificial diet (without the antimicrobial agents). Four replicates (each replicate contained 10 newly hatched larvae $P$. gossypiella). A control experiment was done, but diet was mixed with distilled water. Newly hatched larvae at all treatments were allowed to feed on the treated diet for $48 \mathrm{~h}$; then, alive larvae were transferred individually to glass tubes $(2 \times 7 \mathrm{~cm})$ containing untreated artificial diet. Tubes were plugged with cotton wool and incubated at the above concentrations.

\section{Treatment of early 4th instar larvae}

Early 4th instar $P$. gossypiella larvae were immersed in 5 concentrations of fungi for 30-60 s, and then transferred to a sterile filter paper to dry. Four replicates (each replicate contained 10 individuals of 4th instar larvae). A control experiment was done, but larvae were immersed in distilled water. The 4th instar larvae were transferred by sterile forceps to glass tubes $(2 \times 7 \mathrm{~cm})$ containing untreated artificial diet. Tubes were plugged with cotton wool and incubated at the above conditions. Mortality rate was recorded daily until pupation and adult emergence.

\section{Treatment of pupae}

One-day-old pupae $P$. gossypiella were immersed in different concentrations of fungi for 30-60 s, and then transferred to a sterile filter paper to dry. Four replicates at each concentration treated contained 10 pupae. Pupae were incubated at the above conditions. The mortality rate was recorded daily until adult emergence.

\section{Studied criteria}

- Mortality rate was recorded daily and calculated as percentages.

- Pupation rate was expressed as percent of the successfully developed pupae.

- Emergence rate was expressed as percent of the successfully emerged adults.

- Total mortality percentages were corrected against those of the control by Abbott's formula (Abbott 1925).

- $\mathrm{LC}_{50}$ calculation: corrected percentages of total mortality (between 20 and 84\% mortality) were plotted versus the corresponding concentrations on logarithmic probability paper to obtain the corresponding log-concentration probit lines. The median lethal concentration $\left(\mathrm{LC}_{50}\right)$ of treated insects 
was determined from the established regression lines (Finney 1971).

\section{Results}

\section{Virulence of EPF against eggs}

Table 1 displays the virulence of $M$. anisopliae spore suspensions against the egg of $P$. gossypiella. Egg mortalities were recorded at all concentration levels $(41,33,22$, 17 , and $9 \%$ at $10^{12}, 10^{11}, 10^{10}, 10^{9}$, and $10^{8}$ spores $/ \mathrm{ml}$, respectively, compared to $1.50 \%$ of control eggs). Also, egg hatchability was gradually decreased with the increase of concentration levels. The used concentration levels decreased the egg hatchability to $59,67,78,83$, and 91 than $98.50 \%$ in the control eggs.

B. bassiana spore suspensions exhibited also a mortality effect against the egg of $P$. gossypiella (Table 1 ). The highest egg mortality was recorded by $53 \%$ at concentration level $10^{12}$ spores $/ \mathrm{ml}$ than $2.5 \%$ in the control egg. The same concentration level decreased the egg hatchability to $47 \%$ compared to $97.5 \%$ of control egg.

No latent toxicity effect was recorded for the $2 \mathrm{EPF}$. According to the $\mathrm{LC}_{50}$ values, $B$. bassiana exhibited the lowest $4.97 \times 10^{11}$ spores $/ \mathrm{ml}$, whereas $6.03 \times 10^{12}$ spores/ $\mathrm{ml}$ for M. anisopliae (Table 5).

\section{Virulence of EPF against newly hatched larvae}

$M$. anisopliae exhibited a mortality effect against the newly hatched larvae (neonate) of $P$. gossypiella that increased with the increased of concentration levels (Table 2). Obtained data indicated that the highest mortality percent (92.5\%) was recorded by the highest concentration $\left(10^{12}\right.$ spores $/ \mathrm{ml}$ ) while the lowest mortality percent $(15.0 \%)$ was caused by the lowest concentration $\left(10^{8}\right.$ spores $\left./ \mathrm{ml}\right)$ compared to $7.5 \%$ of control larvae. The mortality effect of $M$. anisopliae extended from the larval treatment to the resulted pupae and adults. Pupal mortality appeared at the highest 3 concentrations: $66.7,20.0$, and $4.5 \%$ at $10^{12}, 10^{11}$, and $10^{10}$ spores $/ \mathrm{ml}$, respectively than $0.0 \%$ in the control pupae. However, $M$. anisopliae induced adult mortality to $37.5,14.3$, and $6.90 \%$ at $10^{11}, 10^{10}$, and $10^{9}$, respectively compared to $0.0 \%$ of control adults. Total mortality was increased gradually by increasing the concentration $\left(97.50,87.5,55.00,32.50\right.$, and 15.00 at $10^{12}, 10^{11}$, $10^{10}, 10^{9}$, and $10^{8}$ spores $/ \mathrm{ml}$, respectively compared to $07.50 \%$ of control insects). Pupation and adult emergence percentages were concentration dependent. Application of the highest concentration level $\left(10^{12}\right.$ spores $/ \mathrm{ml}$ ) decreased the pupation percent to $07.50 \%$ vs. 92.50 of the control pupae and adult emergence percent to $02.50 \%$ vs. $100.00 \%$ of control adults.

$B$. bassiana showed the same effect of $M$. anisopliae on treatment of the newly hatched larvae (neonate) of $P$. gossypiella (Table 2). Complete mortality (100\%) was recorded at the highest concentration level $\left(10^{12}\right.$ spores/ $\mathrm{ml}$ ) compared to control larvae (10.0\%) whereas other tested concentrations caused mortality of 82.5, 70.0, 47.5 , and $32.5 \%$ at $10^{11}, 10^{10}, 10^{9}$, and $10^{8}$ spores $/ \mathrm{ml}$, respectively. Mortality effect of $B$. bassiana was extended in the resulted pupae and adults. In pupal stage, only 2 concentration levels $\left(10^{11}\right.$ and $10^{10}$ spores $\left./ \mathrm{ml}\right)$ revealed a mortality rate of 28.60 and $8.0 \%$ compared to control $(0.0 \%)$. In the adult stage, mortality rates were revealed at all concentration levels with the highest mortality $60.0 \%$ at $10^{11}$ spores $/ \mathrm{ml}$. Total mortality percent was recorded in a concentration-dependent manner $(100.00,95.50,77.50,52.50$, and $37.50 \%$ at $10^{12}, 10^{11}, 10^{10}, 10^{9}$, and $10^{8}$ spores $/ \mathrm{ml}$, respectively vs. $10.00 \%$ of control insects). Pupation and adult emergence percent decreased with increasing the concentration levels (Table 2).

According to the $\mathrm{LC}_{50}$ values of total mortality, $B$. bassiana exhibited the lowest $\mathrm{LC}_{50}, 8.25 \times 10^{8}$ spores $/ \mathrm{ml}$, whereas it was $6.03 \times 10^{9}$ spores $/ \mathrm{ml}$ at $M$. anisopliae (Table 5).

Table 1 Effect of the fungal isolates against the egg stage of Pectinophora gossypiella

\begin{tabular}{|c|c|c|c|c|}
\hline Entomopathogenic fungi & Concentration spores $/ \mathrm{ml}$ & Eggs mortality (\%) & Corrected mortality (\%) & Egg hatchability (\%) \\
\hline \multirow[t]{6}{*}{ Metarhizium anisopliae } & $10^{12}$ & 41.00 & 40.0 & 59.00 \\
\hline & $10^{11}$ & 33.00 & 31.98 & 67.00 \\
\hline & $10^{10}$ & 22.00 & 20.81 & 78.00 \\
\hline & $10^{9}$ & 17.00 & 15.73 & 83.00 \\
\hline & $10^{8}$ & 9.00 & 7.61 & 91.00 \\
\hline & Control & 1.50 & --- & 98.50 \\
\hline \multirow[t]{6}{*}{ Beauveria bassiana } & $10^{12}$ & 53.00 & 51.81 & 47.00 \\
\hline & $10^{11}$ & 44.00 & 42.51 & 56.00 \\
\hline & $10^{10}$ & 32.0 & 30.21 & 68.00 \\
\hline & $10^{9}$ & 24.00 & 22.1 & 76.00 \\
\hline & $10^{8}$ & 12.0 & 9.7 & 88.0 \\
\hline & Control & 2.5 & --- & 97.5 \\
\hline
\end{tabular}


Table 2 Effect of the fungal isolates against the newly hatched larvae (neonate) of Pectinophora gossypiella

\begin{tabular}{|c|c|c|c|c|c|c|c|c|}
\hline $\begin{array}{l}\text { Entomopathogenic } \\
\text { fungi }\end{array}$ & $\begin{array}{l}\text { Concentration } \\
\text { spores } / \mathrm{ml}\end{array}$ & $\begin{array}{l}\text { Larval } \\
\text { mortality (\%) }\end{array}$ & $\begin{array}{l}\text { Pupation } \\
\text { (\%) }\end{array}$ & $\begin{array}{l}\text { Pupal } \\
\text { mortality (\%) }\end{array}$ & $\begin{array}{l}\text { Adult } \\
\text { emergency (\%) }\end{array}$ & $\begin{array}{l}\text { Adult } \\
\text { mortality (\%) }\end{array}$ & $\begin{array}{l}\text { Total } \\
\text { mortality (\%) }\end{array}$ & $\begin{array}{l}\text { Corrected } \\
\text { mortality (\%) }\end{array}$ \\
\hline \multirow{6}{*}{$\begin{array}{l}\text { Metarhizium } \\
\text { anisopliae }\end{array}$} & $10^{12}$ & 92.50 & 07.50 & 66.7 & 02.50 & 0.00 & 97.50 & 97.30 \\
\hline & $10^{11}$ & 75.00 & 25.00 & 20.0 & 20.00 & 37.5 & 87.5 & 78.41 \\
\hline & $10^{10}$ & 45.00 & 55.00 & 4.5 & 52.50 & 14.3 & 55.00 & 43.24 \\
\hline & $10^{9}$ & 27.50 & 72.50 & 00.00 & 100.00 & 6.90 & 32.50 & 21.62 \\
\hline & $10^{8}$ & 15.00 & 85.00 & 00.00 & 100.00 & 0.00 & 15.00 & 8.11 \\
\hline & Control & 07.50 & 92.50 & 00.00 & 100.00 & 0.00 & 07.50 & --- \\
\hline \multirow{6}{*}{$\begin{array}{l}\text { Beauveria } \\
\text { bassiana }\end{array}$} & $10^{12}$ & 100.00 & ----- & --- & ----- & - & 100.00 & 100.00 \\
\hline & $10^{11}$ & 82.50 & 17.50 & 28.60 & 12.50 & 60.0 & 95.50 & 86.11 \\
\hline & $10^{10}$ & 70.00 & 30.00 & 8.0 & 27.50 & 18.1 & 77.50 & 69.44 \\
\hline & $10^{9}$ & 47.50 & 52.50 & 00.00 & 100.00 & 9.25 & 52.50 & 41.67 \\
\hline & $10^{8}$ & 32.50 & 67.50 & 00.00 & 100.00 & 7.41 & 37.50 & 25.00 \\
\hline & Control & 10.00 & 90.00 & 00.00 & 100.00 & 0.00 & 10.00 & --- \\
\hline
\end{tabular}

Virulence of EPF against early 4th instar larvae

Obtained data exhibited that the highest mortality percent in the treated larvae $(57.5 \%)$ was caused by the highest concentration level of $10^{12}$ spores $/ \mathrm{ml}$ whereas the concentrations of $10^{11}, 10^{10}, 10^{9}$, and $10^{8}$ spores $/ \mathrm{ml}$ induced mortality of $45.0,32.5,22.5$, and $15.0 \%$, respectively, compared to $0.00 \%$ in control larvae (Table 3 ). The mortality effect of $M$. anisopliae extended to the pupae and adults that resulted from the treatment. Pupal and adult mortalities were recorded at all concentration levels except the lowest concentration. Pupal mortality rates were $52.9,31.8,18.5$, and $6.5 \%$ at $10^{12}, 10^{11}, 10^{10}$, and $10^{9}$ spores $/ \mathrm{ml}$, respectively, vs. $0.00 \%$ mortality in control. Also, $25.0 \%$ of adult mortality that formed the highest percent was recorded at the highest concentration level $\left(10^{12}\right.$ spores $/ \mathrm{ml}$ ) compared to $2.5 \%$ in control. Total mortality increased with the increased concentration levels to 85.0, $67.5,50.0,30.0$, and $15.0 \%$, respectively, against $2.5 \%$ in control. The highest concentration $\left(10^{12}\right.$ spores $\left./ \mathrm{ml}\right)$ decreased pupation and adult emergence percent with the highest percent to 42.5 and $20.0 \%$, respectively vs. $100 \%$ of control insects.

The fungal isolate $B$. bassiana showed the same trend with $M$. anisopliae but with somewhat high effect (Table 3). All spore suspensions exhibited mortal effects against the treated larvae $\left(65,55,47.5,35\right.$, and $22.5 \%$ at $10^{12}$, $10^{11}, 10^{10}$, and $10^{9}$ spores $/ \mathrm{ml}$, respectively) vs. $2.5 \%$ mortality in control larvae. The virulence activity of the fungus $B$. bassiana was continued in the resulted pupae and adults from larval treatment. Pupal mortality was in a concentration dependent manner. The highest pupal mortality was recorded at the 2 highest spore

Table 3 Effect of the fungal isolates against the early $4^{\text {th }}$ instar Pectinophora gossypiella larvae

\begin{tabular}{|c|c|c|c|c|c|c|c|c|}
\hline $\begin{array}{l}\text { Entomopathogenic } \\
\text { fungi }\end{array}$ & $\begin{array}{l}\text { Concentration } \\
\text { spores } / \mathrm{ml}\end{array}$ & $\begin{array}{l}\text { Larval } \\
\text { mortality } \\
(\%)\end{array}$ & Pupation (\%) & $\begin{array}{l}\text { Pupal } \\
\text { mortality (\%) }\end{array}$ & $\begin{array}{l}\text { Adult } \\
\text { emergence (\%) }\end{array}$ & $\begin{array}{l}\text { Adult } \\
\text { mortality (\%) }\end{array}$ & $\begin{array}{l}\text { Total } \\
\text { mortality (\%) }\end{array}$ & $\begin{array}{l}\text { Corrected } \\
\text { mortality (\%) }\end{array}$ \\
\hline \multirow{6}{*}{$\begin{array}{l}\text { Metarhizium } \\
\text { anisopliae }\end{array}$} & $10^{12}$ & 57.5 & 42.5 & 52.9 & 20.00 & 25.0 & 85.0 & 84.6 \\
\hline & $10^{11}$ & 45.0 & 55.0 & 31.8 & 37.50 & 13.3 & 67.5 & 66.7 \\
\hline & $10^{10}$ & 32.5 & 67.5 & 18.5 & 55.00 & 9.1 & 50.00 & 48.7 \\
\hline & $10^{9}$ & 22.5 & 77.5 & 6.5 & 72.50 & 3.5 & 30.00 & 28.2 \\
\hline & $10^{8}$ & 15.0 & 85.0 & 0.00 & 100.00 & 0.00 & 15.0 & 12.8 \\
\hline & Control & 0.00 & 100.0 & 0.00 & 100.00 & 2.50 & 2.50 & -- \\
\hline \multirow{6}{*}{$\begin{array}{l}\text { Beauveria } \\
\text { bassiana }\end{array}$} & $10^{12}$ & 65.0 & 35.0 & 78.6 & 7.5 & 66.7 & 97.5 & 97.4 \\
\hline & $10^{11}$ & 55.0 & 45.0 & 55.6 & 20.0 & 25.0 & 85.00 & 84.6 \\
\hline & $10^{10}$ & 47.5 & 52.5 & 38.1 & 32.5 & 7.70 & 70.00 & 69.2 \\
\hline & $10^{9}$ & 35.0 & 65.0 & 26.9 & 47.5 & 0.00 & 52.5 & 51.3 \\
\hline & $10^{8}$ & 22.5 & 77.5 & 16.1 & 65.0 & 0.00 & 35.0 & 33.3 \\
\hline & Control & 2.5 & 97.5 & 0.00 & 100.0 & 0.00 & 2.5 & --- \\
\hline
\end{tabular}


suspensions, 78.6 and $55.6 \%$ at $10^{12}$ and $10^{11}$ spores $/ \mathrm{ml}$ than $0.0 \%$ mortality in control pupae. The highest 3 spore suspensions induced adult mortality; the highest mortality was $66.7 \%$ at $10^{12}$ spores $/ \mathrm{ml}$ vs. $0.0 \%$ mortality in control adults. The total mortality was gradually increased by increasing spore suspensions as 97.5, 84.6, 69.2, 51.3 , and $33.3 \%$ vs. $2.2 \%$ mortality in control insects. All concentrations decreased pupation and adult emergence percent in a concentration-dependent manner.

According to $\mathrm{LC}_{50}$ values of total mortality, $B$. bassiana was more effective than $M$. anisopliae against the early 4th instar larvae of $P$. gossypiella. The entomopathogenic fungus $B$. bassiana exhibited the lowest $\mathrm{LC}_{50}, 2.52 \times 10^{8}$ spores $/ \mathrm{ml}$, whereas the $\mathrm{LC}_{50}$ of $M$. anisopliae recorded $1.29 \times 10^{10}$ spores $/ \mathrm{ml}$ (Table 5 ).

\section{Virulence of EPF against the pupae}

The highest spore suspension of $M$. anisopliae, $10^{12}$ spores $/ \mathrm{ml}$, caused a high percent of pupal mortality, $72.5 \%$ and $45.6 \%$ of adult mortality after treatment of $P$. gossypiella pupae, compared to 5.0 and $2.5 \%$, respectively, for control (Table 4), whereas the other concentrations of $10^{11}, 10^{10}, 10^{9}$, and $10^{8}$ spores $/ \mathrm{ml}$ caused 65.0 , $47.5,32.5$, and $17.5 \%$ pupal mortality rates and 24.6 , 14.3, 11.1, and $3.0 \%$ adult mortalities. Total mortality was increased with the increase of concentration levels as $85.0,75.0,55.0,40.0$, and $20.0 \%$ at $10^{12}, 10^{11}, 10^{10}$, $10^{9}$, and $10^{8}$ spores $/ \mathrm{ml}$, respectively, compared to $7.5 \%$ of control insects. The percent of adult emergence decreased gradually to $82.5,67.5,52.5,35.0$, and $27.5 \%$ at the same ascending fungal concentrations than $95.0 \%$ of control adults.

The effect of B. bassiana treatment against $P$. gossypiella pupae and its extended to the emerged adults is showed in Table 4. B. bassiana showed pupal mortality rates of 85.0, 77.5, 70.0, 47.5, and $35.0 \%$ at concentrations of $10^{12}, 10^{11}, 10^{10}, 10^{9}$, and $10^{8}$ spores/ $\mathrm{ml}$, respectively, compared to $2.5 \%$ for control pupae. Also the effect was spread in the emerged adults, where the same spore suspensions exhibited a slight activity by 5.0, 7.5, 7.5, 5.0, and $2.5 \%$ vs. $2.5 \%$ for control adults. Total mortality was in a concentration-dependent manner as $90.0,85.0,77.5,52.5,37.5 \%$ at $10^{12}, 10^{11}, 10^{10}$, $10^{9}$, and $10^{8}$ spores $/ \mathrm{ml}$, respectively, compared to $5.0 \%$ for control insects. Adult emergence was inhibited by the highest percent to $15.0,22.5,30,52.5$, and $65.0 \%$ at the used fungal concentrations vs. $97.5 \%$ of control adults.

Based on $\mathrm{LC}_{50}$ values for total mortality, $B$. bassiana was more potent than $M$. anisopliae against $P$. gossypiella after treatment of the early pupal stage. Obtained data exhibited that the $B$. bassiana recorded the lowest $\mathrm{LC}_{50}, 6.79 \times 10^{8}$ spores $/ \mathrm{ml}$, whereas the $\mathrm{LC}_{50}$ of $M$. anisopliae was $8.36 \times 10^{9}$ spores $/ \mathrm{ml}$ (Table 5). Depending on the previous data of $\mathrm{LC}_{50}$ values for $\mathrm{EPF}$, the lowest affected immature stages were eggs.

\section{Discussion}

Entomopathogenic fungi currently present as an alternative tool for pest control. Several strains of B. bassiana, $M$. anisopliae, and other fungal isolates have been evaluated against $P$. gossypiella (El-Akad et al. 2016; Moustafa et al. 2019) and several other insect pests.

In the present study, the 2 fungal isolates, $B$. bassiana and $M$. anisopliae, proved their virulence against $P$. gossypiella irrespective of the treated stage. The newly hatched larvae were more susceptible than the 4th instar larvae after treatment with $B$. bassiana than $M$. anisopliae. Accordingly, the $\mathrm{LC}_{50}, B$. bassiana isolate was more potent than $M$. anisopliae isolate in inducing mortality. Farooq et al. (2020) found that B. bassiana, V. lecanii, and $M$. anisopliae concentrations and $A$. indica

Table 4 Effect of the fungal isolates against pupal stage of Pectinophora gossypiella

\begin{tabular}{|c|c|c|c|c|c|c|}
\hline $\begin{array}{l}\text { Entomopathogenic } \\
\text { fungi }\end{array}$ & $\begin{array}{l}\text { Concentration } \\
\text { spores } / \mathrm{ml}\end{array}$ & Pupal mortality (\%) & Adult emergence (\%) & Adult mortality (\%) & Total mortality (\%) & $\begin{array}{l}\text { Corrected } \\
\text { mortality (\%) }\end{array}$ \\
\hline \multirow[t]{6}{*}{ Metarhizium anisopliae } & $10^{12}$ & 72.50 & 27.5 & 45.6 & 85.0 & 83.75 \\
\hline & $10^{11}$ & 65.00 & 35.00 & 28.6 & 75.0 & 72.9 \\
\hline & $10^{10}$ & 47.50 & 52.50 & 14.3 & 55.0 & 51.35 \\
\hline & $10^{9}$ & 32.5 & 67.50 & 11.1 & 40.0 & 35.13 \\
\hline & $10^{8}$ & 17.5 & 82.5 & 3.0 & 20.0 & 13.5 \\
\hline & Control & 5.00 & 95.0 & 2.5 & 7.5 & --- \\
\hline \multirow[t]{6}{*}{ Beauveria bassiana } & $10^{12}$ & 85.0 & 15.00 & 5.00 & 90.0 & 89.47 \\
\hline & $10^{11}$ & 77.5 & 22.50 & 7.50 & 85.00 & 84.21 \\
\hline & $10^{10}$ & 70.0 & 30.00 & 7.5 & 77.5 & 76.32 \\
\hline & $10^{9}$ & 47.5 & 52.50 & 5.0 & 52.5 & 50.0 \\
\hline & $10^{8}$ & 35.0 & 65.00 & 2.5 & 37.5 & 34.2 \\
\hline & Control & 2.50 & 97.50 & 2.5 & 5.0 & --- \\
\hline
\end{tabular}


Table $\mathbf{5} \mathrm{LC}_{50}$ values of the fungal isolates on different stages of Pectinophora gossypiella

\begin{tabular}{llll}
\hline Entomopathogenic fungi & $\mathrm{LC}_{\mathbf{5 0}}{ }^{*}$ spores/ml & Lower limit spores/ml & Upper limit spores/ml \\
\hline Egg stage & & & $3.94 \times 10^{13}$ \\
$\quad \begin{array}{l}\text { Metarhizium anisopliae } \\
\text { Beauveria bassiana }\end{array}$ & $6.03 \times 10^{12}$ & $1.74 \times 10^{12}$ & $1.43 \times 10^{12}$ \\
Newly hatched larvae & $4.97 \times 10^{11}$ & $2.25 \times 10^{11}$ & $1.11 \times 10^{10}$ \\
$\quad$ & & $3.23 \times 10^{9}$ & $1.74 \times 10^{9}$ \\
$\quad$ Metarhizium anisopliae & $6.03 \times 10^{9}$ & $3.25 \times 10^{8}$ & $3.11 \times 10^{10}$ \\
Early 4th instar larvae & $8.25 \times 10^{8}$ & & $8.35 \times 10^{8}$ \\
$\quad$ Metarhizium anisopliae & & $5.48 \times 10^{9}$ & $2.03 \times 10^{9}$ \\
$\quad$ Beauveria bassiana & $1.29 \times 10^{10}$ & & $2.02 \times 10^{10}$ \\
Pupal stage & $2.52 \times 10^{8}$ & $3.4 \times 10^{9}$ & $1.93 \times 10^{9}$ \\
$\quad \begin{array}{l}\text { Metarhizium anisopliae } \\
\text { Beauveria bassiana }\end{array}$ & $8.36 \times 10^{9}$ & $1.47 \times 10^{8}$ & \\
\hline
\end{tabular}

${ }^{*} \mathrm{LC}_{50}$ was calculated for total mortality (between 20 and $84 \%$ mortality)

extract (alone and in combination) at different exposure intervals caused high mortality rates among the treated 2nd instar P. gossypiella larvae. Also, $\mathrm{LC}_{50}$ values for $P$. gossypiella larvae treated with different concentrations of $B$. bassiana and M. anisopliae were 1.42 and $0.98 \mathrm{~g} / \mathrm{l}$, respectively (El-Akad et al. 2016). Moustafa et al. (2019) showed that the virulence of Paecilomyces lilicanus was high on $P$. gossypiella whereas the toxicity of $M$. anisopliae was high in case of Earias insulana after treatment of the newly hatched larvae. Trichoderma harzianum spores induced mortalities against the larvae of $E$. insulana and P. gossypiella (El-Massry et al. 2016).

The present study revealed that the treated eggs of $P$. gossypiella were less susceptible to the EPF than the other treated immature stages including the pupal stage depending on the $\mathrm{LC}_{50}$. It is broadly accepted that insect eggs are more difficult to be infected than the larval stage (Skinner et al. 2014) and that the pupal stage is typically very resistant to succumb to injury (Vestergaard et al. 1995). However, the tested EPF, B. bassiana and $M$. anisopliae, decreased the egg hatchability of P. gossypiella. This result agrees with the study of Ullah et al. (2019) who reported that the EPF, I. fumosorosea and B. bassiana, significantly affected the egg hatchability of Spodoptera litura. Obtained data corroborated the findings of other studies that recorded pupal mortalities that extended after treatment of the larvae of some insects by some fungal isolates as in E. insulana (Abd-ElAzeem et al. 2019). In addition, the toxic effect of the 2 fungal isolates was reflected on the percent of pupation and adult emergence that decreased. These data are in accordance with other studies on certain insects by fungal isolates as in P. gossypiella (El-Akad et al. 2016) and E. insulana (Abd-ElAzeem et al. 2019).

Enzyme activity is considered one of the main mechanisms of fungal infection to insect host and inducing mortality by desiccation through the imperfect cuticle (Hamadah et al. 2018). Several studies revealed the presence of hydrolytic enzyme activity or cuticle-degrading enzymes, as chitinase, protease, and lipase, that play the main mechanism of fungal infection to insect host and inducing mortality. Also, some studies revealed that the virulence of EPF is associated with cuticle-degrading enzymes (Sargin et al. 2013; Cristina and Gheorghe 2017; Hamadah et al. 2018). These proteases are believed to help the fungal hyphae in penetrating the host tissue by breaking down the protein linkages in the insect cuticle and/or the utilization of the host proteins for fungal nutrition (Pozo et al. 2004). On the other hand, another suggestion that may be acceptable for the toxic effect of the fungal isolates is the complete destruction of the fat bodies; thus, the fat bodies lose their ability to synthesize and capacity to store nutrients (Mitchell and Cali 1994).

\section{Conclusions}

The study proved the activity of EPF, B. bassiana and $M$. anisopliae, against different stages of $P$. gossypiella under laboratory conditions. So, there is a possibility to use EPF as an alternative control tool to synthetic insecticides. Further study is needed to show their activity under field conditions.

\section{Abbreviations \\ P. gossypiella: Pectinophora gossypiella; B. bassiana: Beauveria bassiana; $M$. anisopliae: Metarhizium anisopliae; I. fumosorosea: Isaria fumosorosea; E. insulana: Earias insulana; V. lecanii: Verticillium lecanii; EPF: Entomopathogenic fungi}

\section{Acknowledgements}

Not applicable.

Authors' contributions

Al prepared fungal isolates and concentrations; GO conducted experiments and prepared statics; $\mathrm{KH}$ wrote the paper and interpreted the data. The authors read and approved the final manuscript. 
Funding

Personally funded.

\section{Availability of data and materials}

All data generated or analyzed during this study are included in this published article.

\section{Declarations}

Ethics approval and consent to participate

Not applicable.

\section{Consent for publication}

Not applicable.

\section{Competing interests}

The authors declare that they have no competing interests.

\section{Author details}

'Zoology and Entomology Department, Faculty of Science, Al-Azhar University, Madinat Nasr, Cairo, Egypt. ${ }^{2}$ Plant Protection Research Institute, Agricultural Research Center, Dokki, Giza, Egypt.

Received: 19 March 2021 Accepted: 26 June 2021

Published online: 09 July 2021

\section{References}

Abbott WS (1925) A method for computing the effectiveness of insecticides. Econ Entomol 18(2):265-267. https://doi.org/10.1093/jee/18.2.265a

Abd-ElAzeem EM, El-Medany WAZ, Sabry HM (2019) Biological activities of spores and metabolites of some fungal isolates on certain aspects of the spiny bollworms Earias insulana (Boisd.) (Lepidoptera: Noctuidae). Egypt J Biol Pest Cont 29:90

Ali S, Zhang C, Wang Z, Wang XM, Wu JH, Cuthbertson AGS, Shao Z, Qiu BL (2017) Toxicological and biochemical basis of synergism between the entomopathogenic fungus Lecanicillium muscarium and the insecticide matrine against Bemisia tabaci (Gennadius). Sci Rep 7(1):46558. https://doi. org/10.1038/srep46558

Cristina P, Gheorghe S (2017) The role of hydrolytic enzymes produced by entomopathogenic fungi in pathogenesis of insects mini review. Romanian $J$ for Plant Prot 10:2248-2248

Cuthbertson AGS, Audsley N (2016) Further screening of entomopathogenic fungi and nematodes as control agents for Drosophila suzukii. Insects 7(24):19. https://doi.org/10.3390/insects7020024

Dhakal R, Singh DN (2019) Biopesticides: a key to sustainable agriculture. Int Pure App Biosci 7(3):391-396. https://doi.org/10.1186/s41938-019-0192-y

El-Akad AS, El-Banna AA, Abd El-Wahab IS, Abd El-Aal AE, Amin NS (2016) Effects of Beauveria bassiana and Metarhizium anisopliae on some biological aspect of Pectinophora gossypiella (Saunders) (Lepidoptera: Gelechiidae). Egypt Acad J Biol Sci 9(3):31-39. https://doi.org/10.21608/eajbsa.2016.12772

El-Massry SAA, Shokry HG, Hegab MEM (2016) Efficiency of Trichoderma harzianum and some organic acids on the cotton bollworms, Earias insulana and Pectinophora gossypiella. J Plant Prot and Path Mansoura 7(2):143-148

Faroog MA, Atta B, Gogi MD, Arif MJ, Arain QA (2020) Compatibility of entomopathogenic fungi and Azadirachta indica extract against the cotton pink bollworm, Pectinophora gossypiella (Saunders) (Lepidoptera: Gelechiidae) under controlled conditions. Egypt J Biol Pest Cont 30(1):63. https://doi.org/1 0.1186/s41938-020-00260-x

Finney DJ (1971) Probit analysis. Cambridge, University Press, Cambridge, p 120 Hamadah K, Zahran M, El-Hosainy A (2018) Virulence of some selected fungal isolates against the cotton leafworm, Spodoptera littoralis (Lepidoptera: Noctuidae). Egypt Acad J Biol Sci 10(2):25-53. https://doi.org/10.21608/ea jbsg.2018.28877

Hanem FK (2012) Ecosmart biorational insecticides. In: Farzana P (ed) Insecticides: alternative insect control strategies, vol 17. Tech Publishing. ISBN 978-953307-780-2, Rijekap, pp 34-35

Ibrahim AA (2006) Action of certain microbes on cotton leaf worm. Ph. D. Thesis, Faculty of Science. Al_Azhar University, p 171

Mitchell MJ, Cali A (1994) Vairimorpha necatrix (Microsporidia: Burenellidae) affects growth and development of Heliothis zea (Lepidoptera: Noctuidae) raised at various temperatures. J Econ Entomol 87(4):933-940. https://doi. org/10.1093/jee/87.4.933

Moustafa HZ, Lotfy DE, Karim AH (2019) Effect of entomopathogenic fungi on Pectinophora gossypiella (Lepidoptera: Gelechiidae) and Earias insulana (Lepidoptera: Noctuidae) and their predators. Egypt J Plant Prot Res Inst 2(1): $9-15$

Niu X, Xie W, Zhang J, Hu Q (2019) Biodiversity of entomopathogenic fungi in the soils of South China. Microorganisms 7(9):311. https://doi.org/10.3390/ microorganisms 7090311

Parmar VR, Patel CC (2016) Pink bollworm: a notorious pest of cotton: a review. -AGRES. Int e-J 5(2):88-97

Pozo MJ, Baek J-M, Juan M, Kenerley CM (2004) Functional analysis of tvsp1, a serine protease-encoding gene in the biocontrol agent Trichoderma virens. Fungal Genet Biol 41(3):336-348. https://doi.org/10.1016/j.fgb.2003.11.002

Rashad AM, Nada MA, Abd El-Salam NM (1993) Effect of some factors on diapausing larvae and emerging moths of the pink bollworm, Pectinophora gossypiella (Saunders). Egypt J Appl Sci 8(1):488-500

Rizwan M, Atta B, Sabir AM, Yaqub M, Qadir A (2019) Evaluation of the entomopathogenic fungi as a non-traditional control of the rice leaf roller, Cnaphalocrocis medinalis (Guenee) (Lepidoptera: Pyralidae) under controlled conditions. Egypt J Biol Pest Cont 29(1):10. https://doi.org/10.1186/s41938-01 9-0111-2

Sargin S, Gezgin Y, Eltem R, Vardar F (2013) Micropropagule production from Trichoderma harzianum EGE-K38 using solid-state fermentation and a comparative study for drying methods. Turk J Biol 37:139-146. https://doi. org/10.3906/biy-1206-32

Skinner M, Parker BL, Kim JS (2014) Role of entomopathogenic fungi in integrated pest management. In: Abrol DP (ed) Integrated Pest Management. Academic Press, San Diego, pp 169-191 ISBN 978-0-12-398529-3

Ullah ML, Altaf N, Afzal M, Arshad M, Mehmood N, Riaz M, Majeed S, Ali S, Abdullah A (2019) Effects of entomopathogenic fungi on the biology of Spodoptera litura (Lepidoptera: Noctuidae) and its reduviid Predator, Rhynocoris marginatus (Heteroptera: Reduviidae). Int J Insect Sci 11:1-7. https://doi.org/10.1177/1179543319867116

Vega FE, Goettel MS, Blackwell M, Chandler D, Jackson MA, Keller S, Koike M, Maniania NK, Monzón A, Ownley BH, Pell JK, Rangel DEN, Roy HE (2009) Fungal entomopathogens: new insights on their ecology. Fungal Ecol 2(4): 149-159. https://doi.org/10.1016/j.funeco.2009.05.001

Vestergaard S, Gillespie AT, Butt TM, Schreiter G, Eilenberg J (1995) Pathogenicity of the Hyphomycete Fungi Verticillium lecanii and Metarihizium anisopliae to the Western Flower Thrips, Frankliniella occidentalis. Biocont Sci Technol 5(2): 185-192. https://doi.org/10.1080/09583159550039909

\section{Publisher's Note}

Springer Nature remains neutral with regard to jurisdictional claims in published maps and institutional affiliations.

\section{Submit your manuscript to a SpringerOpen ${ }^{\circ}$ journal and benefit from:}

- Convenient online submission

- Rigorous peer review

- Open access: articles freely available online

High visibility within the field

- Retaining the copyright to your article

Submit your next manuscript at $\boldsymbol{\nabla}$ springeropen.com 